Article (refereed) - postprint

Ford, Hilary; Roberts, Aled; Jones, Laurence. 2016. Nitrogen and phosphorus co-limitation and grazing moderate nitrogen impacts on plant growth and nutrient cycling in sand dune grassland.

2015 Elsevier B.V.

This manuscript version is made available under the CC-BY-NC-ND 4.0 license http://creativecommons.org/licenses/by-nc-nd/4.0/

$(\mathrm{cc})$ EY-NC-ND

This version available http://nora.nerc.ac.uk/512180/

NERC has developed NORA to enable users to access research outputs wholly or partially funded by NERC. Copyright and other rights for material on this site are retained by the rights owners. Users should read the terms and conditions of use of this material at http://nora.nerc.ac.uk/policies.html\#access

NOTICE: this is the author's version of a work that was accepted for publication in Science of the Total Environment. Changes resulting from the publishing process, such as peer review, editing, corrections, structural formatting, and other quality control mechanisms may not be reflected in this document. Changes may have been made to this work since it was submitted for publication. A definitive version was subsequently published in Science of the Total Environment (2015), 542 (A). 203-209.

10.1016/i.scitotenv.2015.10.089

www.elsevier.com/

\author{
Contact CEH NORA team at \\ noraceh@ceh.ac.uk
}

The NERC and CEH trademarks and logos ('the Trademarks') are registered trademarks of NERC in the UK and other countries, and may not be used without the prior written consent of the Trademark owner. 


\title{
Nitrogen and phosphorus co-limitation and grazing moderate nitrogen impacts on plant growth and nutrient cycling in sand dune grassland
}

Hilary Ford ${ }^{a, b} *$, Aled Roberts ${ }^{b}$ and Laurence Jones ${ }^{b}$

a School of Ocean Sciences, Bangor University, Anglesey, LL59 5AB, UK;

${ }^{b}$ Centre for Ecology and Hydrology, Environment Centre Wales, Bangor, LL57 2UW, UK

* Corresponding author. E-mail addresses: hilary.ford@bangor.ac.uk (H. Ford), lj@ceh.ac.uk (L. Jones).

\begin{abstract}
Atmospheric nitrogen $(\mathrm{N})$ deposition alters plant biodiversity and ecosystem function in grasslands worldwide. This study examines the impact of 6 years of nutrient addition and grazing management on a sand dune grassland. Results indicate that co-limitation of $\mathrm{N}$ and phosphorus $(\mathrm{P})$ moderates the impact of realistic rates of $\mathrm{N}$ addition $\left(7.5,15 \mathrm{~kg} \mathrm{~N} \mathrm{ha}^{-1}\right.$ year $^{-1}$ ). Combined NP addition (15 kg N $+10 \mathrm{~kg} \mathrm{P} \mathrm{ha}^{-1}$ year $^{-1}$ ) was the only nutrient treatment to differ significantly from the control, with greater above-ground biomass (mainly moss), and enhanced $\mathrm{N}$ and $\mathrm{P}$ mineralisation rates. Grazing management altered plant functional group composition, reduced above-ground biomass and meso-faunal feeding rates, and decoupled $\mathrm{N}$ and $\mathrm{P}$ mineralisation. There were no synergistic effects of grazing and $\mathrm{N}$ treatment. Although NP co-limitation apparently prevents adverse impacts of $\mathrm{N}$ deposition above the critical load, excess $\mathrm{N}$ is likely to be stored in moss biomass and soil, with unknown future consequences.
\end{abstract}

Capsule: This study shows that at realistic levels of N addition, NP co-limitation in a dune grassland appears to prevent adverse impacts of $\mathrm{N}$ on plant growth and nutrient cycling.

Key words: Critical load, biodiversity, nitrogen deposition, bait lamina, mineralisation 


\section{Introduction}

Atmospheric nitrogen $(\mathrm{N})$ deposition is an increasing global problem with clear consequences for grassland ecosystem function (Bobbink et al., 2010; Phoenix et al., 2012). The world's N cycle is now largely controlled by human activity (Galloway et al., 2004) with two main sources of $\mathrm{N}$ : ammonia from agriculture and nitrogen oxides from fossil fuel combustion (ROTAP, 2012). Nutrient enrichment via $\mathrm{N}$ deposition is threatening the diversity of species rich grasslands that are diverse precisely because of their low nutrient soil status (Bobbink and Willems, 1987; Stevens et al. 2011; Field et al. 2014; Jones et al. 2014). In addition to plant composition change, $\mathrm{N}$ addition can also alter plant available $\mathrm{N}$, nutrient cycling and soil pH (Phoenix et al., 2012) leading to further changes in ecosystem functioning. Phosphorus (P) limitation is common in many semi-natural grassland soils, especially calcareous grasslands (Willems et al., 1993; Carroll et al., 2003; Vitousek et al., 2010) where $\mathrm{P}$ availability is partly determined by soil $\mathrm{pH}$, forming complexes with calcium at high pH (Kooijman and Besse, 2002). As a result, plant growth may be limited by P supply (Jeffrey and Pigott, 1973; Morecroft et al., 1994; van den Berg et al., 2005), thereby reducing some of the negative impacts of $\mathrm{N}$ deposition mediated through above-ground competition for light (Ten Harkel and van der Meulen, 1996; Vitousek et al., 2010).

In addition to soil nutrient status the maintenance of species-rich grasslands often depends on the activity of grazing animals (Ten Harkel and van der Meulen, 1996). Grazing management of low productivity grasslands, either for food production or conservation, maintains high plant diversity and influences both plant composition and nutrient cycling (Ford et al., 2012a), potentially interacting with the effects of $\mathrm{N}$ addition (Bardgett and Leemans, 1995). Grazers such as ponies, sheep, cattle and rabbits can reduce the dominance of tall grasses and maintain a short sward of species rich forbs (Bakker, 2003; Ford et al., 2012a; Millett and Edmondson, 2013; van Dijk 1992). Decomposition and nutrient cycling may also be altered by grazing management. Classic theory suggests that grazed land will be dominated by faster bacterial nutrient cycling and un-grazed grassland by slower fungal cycling (McNaughton et al., 1997; Bardgett et al., 1998) due to altered plant litter quality. However, this is not always the case, with both net nitrification and $\mathrm{N}$ 
mineralisation rates lower in grazed than in un-grazed coastal grassland (Ford et al., 2012a; Ford et al., 2013). Nutrient cycling is important as it determines plant available $\mathrm{N}$, a limiting factor for plant primary productivity (Bardgett et al., 2011), mediated by grassland decomposition rate. Soil organic matter decomposition can be measured by mineralisation assays and by the biological activity of soil meso-faunal decomposers using bait lamina (Ford et al., 2012b) and is likely to be enhanced by $\mathrm{N}$ addition treatments in grass-dominated habitats due to enhanced litter quality and palatability (Gong et al., 2015). There is a theoretical contrast apparent between the impact of enhanced $\mathrm{N}$ additions, expected to increase $\mathrm{N}$ cycling rates, and grazing which might increase or decrease $\mathrm{N}$ cycling, depending on which theory you subscribe to. Therefore, grazing could either exacerbate or moderate effects of $\mathrm{N}$ deposition on nutrient cycling.

This study aimed to assess the impact of realistic $\mathrm{N}$ addition and grazing management on plant functional type, above and below-ground biomass and nutrient cycling in a speciesrich sand dune grassland of circum-neutral $\mathrm{pH}$. The experiment fulfils three key criteria which many $\mathrm{N}$ deposition experiments fail to meet (Phoenix et al., 2012): i) Long time scales - here $\mathrm{N}$ addition treatments were applied for 6 years prior to the measurements currently presented; ii) Realistic $\mathrm{N}$ loadings $\left(7.5-15 \mathrm{~kg} \mathrm{~N} \mathrm{ha}^{-1}\right.$ year $\left.{ }^{-1}\right)$ on top of a relatively low background $\mathrm{N}$ level of $11 \mathrm{~kg} \mathrm{~N} \mathrm{ha}^{-1}$ year $^{-1}$ (Jones et al., 2013); iii) Frequent applications of $\mathrm{N}-$ $\mathrm{N}$ addition treatments were applied once a month at realistic solute concentrations. We propose the following three hypotheses: 1) The impact of $\mathrm{N}$ addition on plant composition and plant biomass and nutrient cycling in sand dune grasslands will be moderated by soil $\mathrm{P}$ limitation; 2) Grazing management will alter ecosystem characteristics, with the removal of large herbivores leading to a shift towards increased grass cover, fewer forbs, greater above-ground biomass and faster nutrient cycling; 3 ) There will be an interaction of grazing and nitrogen, with grazing management moderating $\mathrm{N}$ impacts on plant biomass and nutrient cycling. 


\section{Materials and Methods}

\subsection{Study site and experimental design}

Fixed sand dune grasslands are species rich, low-productivity semi-natural grasslands, and a European designated Annex 1 habitat. Newborough Warren is a calcareous coastal sand dune grassland, located in NW Wales (53 $\left.3^{\circ} 59^{\prime \prime} \mathrm{N}, 4^{\circ} 21^{\prime} 1^{\prime \prime} \mathrm{W}\right)$, noted for its high biodiversity and designated as a National Nature Reserve, Site of Special Scientific Interest and Special Area of Conservation (Natura 2000 site) under the EC Habitats and Species Directive 1992. The 389 ha site is managed by Natural Resources Wales (NRW) and grazed by ponies (Equus ferus caballus; 0.2 ha $^{-1}$ ), cattle (Bos Taurus; 0.05 ha $^{-1}$ ) and rabbits (Oryctolagus cuniculus; 45 ha $^{-1}$ ), to maximise plant diversity (Maddock, 2008; Plassmann et al. 2009). Grazed vegetation is characteristic of UK National Vegetation Classification (NVC) plant communities: Carex arenaria - Festuca ovina - Agrostis capillaris dune grassland (SD12) and Festuca rubra - Galium verum fixed dune grassland (SD8) (Rodwell, 2000). In 2003, three replicate experimental blocks, each containing three $10 \times 10$ m experimental units: one fully grazed unit (unfenced), one rabbit grazed unit (fenced with $10 \times 10 \mathrm{~cm}$ mesh to exclude large grazers) and one un-grazed unit (fenced with $10 \times 10 \mathrm{~cm}$ mesh and an additional $2.7 \times$ $3.7 \mathrm{~cm}$ mesh buried $20 \mathrm{~cm}$ underground to prevent rabbit access) were set up as described by Plassmann et al. (2009). Small mammals such as field voles (Microtus agrestis) and invertebrate herbivores were assumed to be present within all experimental units. Fully grazed units are denoted as PR (pony and rabbit grazed); rabbit grazed units as $R$ and ungrazed units as $\mathrm{U}$. Two years prior to the measurements in this study, the rabbit population was drastically reduced by an outbreak of viral haemorrhagic disease. Without large grazers accessing these experimental plots to keep the sward short, when the rabbit population recovered the following year they did not return to these plots, preferring to remain in the shorter turf of the fully-grazed areas. Thus, the rabbit grazed treatment was (rabbit) grazed for 4 years, and then un-grazed for 2 years. It therefore represents a sward in transition, retaining some un-grazed characteristics (high sward height), but with residual characteristics of rabbit activity (altered nutrient cycling). 
Within each grazing experimental unit five different nutrient treatments were applied: watered control (Control), low $\mathrm{N}$ treatment of $7.5 \mathrm{~kg} \mathrm{~N} \mathrm{ha}^{-1}$ year-1 (Low N), high $\mathrm{N}$ treatment of $15 \mathrm{~kg} \mathrm{~N} \mathrm{ha}^{-1}$ year $^{-1}$ (High N), P treatment of $10 \mathrm{~kg} \mathrm{P} \mathrm{ha}^{-1}$ year $^{-1}(\mathrm{P})$ and high NP treatment of $15 \mathrm{~kg} \mathrm{~N} \mathrm{ha}^{-1}$ year $^{-1}$ and $10 \mathrm{~kg} \mathrm{P} \mathrm{ha}^{-1}$ year $^{-1}$ (High NP). All treatment plots measured $2 \times 2$ $\mathrm{m}$ and were located at least $1.5 \mathrm{~m}$ from the fence line and $0.75 \mathrm{~m}$ from each other to minimise edge effects. $\mathrm{N}$ was evenly applied over each treatment plot as ammonium nitrate, made up to $5 \mathrm{~L}$ with deionised water, once a month from June 2003 onwards. The watered control received $5 \mathrm{~L}$ of deionised water per month. Low and High $\mathrm{N}$ treatments started in 2003, the High NP treatment in 2004 and the P-only addition plot (P) later in the experiment, in early spring 2009 , prior to the growing season.

\subsection{Plant biomass and functional group}

Six years after the start of the experiment, vegetation, including standing dead material, was harvested from two $25 \times 25 \mathrm{~cm}$ squares for each nitrogen treatment, cut to ground level in autumn at the end of the growing season. Vegetation was then stored at $4{ }^{\circ} \mathrm{C}$ and subsequently sorted into functional groups (forbs, graminoids, bryophytes and lichens). Vegetation was dried at $65{ }^{\circ} \mathrm{C}$ in a fan oven for 24 hours to give a measure of above ground or 'shoot' biomass. At the same time, root biomass was sampled by extracting two $50 \mathrm{~cm}$ deep soil cores of $5 \mathrm{~cm}$ diameter per treatment plot using plastic corers. These cores were divided into three depth zones: $0-15,15-30$ and $30-50 \mathrm{~cm}$, soil removed via washing and roots dried at $65^{\circ} \mathrm{C}$ for 24 hours to give an indication of root biomass.

\subsection{Soil parameters}

Soil moisture content and temperature were recorded in situ within each treatment plot, during autumn 2009. Soil moisture was calculated from conductivity measurements in direct volts using a Delta $T$ Theta Meter $\mathrm{HH} 1$ across $0-6 \mathrm{~cm}$ depth and converted to percentage soil moisture content using a standard calibration suitable for mineral soils. Soil temperature was measured using a digital thermometer down to $11 \mathrm{~cm}$ depth. In the summer, paired soil cores to $15 \mathrm{~cm}$ depth were taken from one corner of each $\mathrm{N}$ plot, using 
plastic corers, capped at both ends to minimise soil disruption. After preparation for mineralisation assays, loss-on-ignition, at $375{ }^{\circ} \mathrm{C}$ for $16 \mathrm{~h}$ was used to estimate organic matter content, and soil $\mathrm{pH}$ in de-ionised water (weight by volume 1:2.5) was determined using a Corning pH meter 220.

\subsection{Decomposition (meso-faunal feeding rates)}

Litter breakdown via meso-faunal detritivores was measured in autumn using two bait lamina (Terra Protecta GmbH, Germany) in each of the 45 nutrient treatment plots ( $2 \mathrm{~m}$ apart, diagonal corners). Bait lamina were left in situ for 38 days from late October and through November. Meso-faunal feeding rate was standardised to $\%$ of bait eaten per 7 days. Data from the two bait lamina per plot were averaged prior to statistical analysis.

\subsection{Nutrient cycling}

Plant and microbially available nitrogen $(\mathrm{N})$ and phosphorus $(\mathrm{P})$ were measured by $\mathrm{N}$ mineralisation assays and the Olsen P method (Olsen et al., 1954) calculated from the two paired $15 \mathrm{~cm}$ depth soil cores per split plot for each assay. The $\mathrm{N}$ mineralisation assay was conducted as follows. One batch of cores from each pair was extracted immediately in $1 \mathrm{M}$ $\mathrm{KCl}$. The second batch was air-dried, then brought to standardised water content by addition of $60 \mathrm{ml}$ de-ionised water ( $60 \%$ water holding capacity) (Robertson et al. 1999). These were incubated for 28 days at $10{ }^{\circ} \mathrm{C}$, before extraction in $1 \mathrm{M} \mathrm{KCl}$ as above. Net nitrification and ammonification rates were calculated over these $28 \mathrm{~d}$, and were expressed as $\mu \mathrm{g} \mathrm{N}$ ( $\mathrm{g}^{-1}$ organic matter) $\mathrm{d}^{-1}$. Due to the strong temperature-dependency of the Olsen $\mathrm{P}$ extraction process the $\mathrm{P}$ mineralisation cores were treated differently. The soil cores were air-dried and brought to 60\% water holding capacity (as above). They were then incubated for 122 days at $10^{\circ} \mathrm{C}$, before extraction by $\mathrm{NaHCO} 3$ using the Olsen P method. Results were expressed as $\mu \mathrm{g} P$ ( $\mathrm{g}^{-1}$ organic matter) $\mathrm{d}^{-1}$. 


\subsection{Statistical analysis}

The effect of grazing and nutrient addition 'treatment' on each measured variable was analysed using the ANOVA output of a linear mixed effects model (Ime) in R (R Development Core Team, 2014) e.g. Ime (temperature $\sim$ grazing*treatment, random = $\sim 1$ |block/grazing/treatment). This approach was used to enable the raw data to be analysed accounting for replication at the level of the experimental block (grazing; $n=3$ ) and the split-plot design of the experiment with nutrient treatments nested within grazing units. Results of best model fit were presented here based on lowest Akaike information criterion (AIC) number and quantile probability plot (qqnorm) with most normal distribution. Where ANOVA results showed a significant grazing effect, differences between pairs of grazing treatments ( $P R$ and $R$; $P R$ and $U$ ), were reported directly from the Ime summary output. As the remaining treatment pair ( $R$ and $U$ ) could not be 'read' directly from the Ime summary, the difference between values for $R$ and $U$ in relation to PR was divided by the standard error to give a number (\#) for the following calculation ' $2 \times(1-$ pt(\#,d.f. = 4))' This gives a probability value for the difference between $\mathrm{R}$ and $\mathrm{U}$ for a twotailed test where d.f. $=4$. Significant differences between pairs of nutrient treatment types were calculated using the same method.

\section{Results}

\subsection{Plant biomass and functional group}

The nutrient addition treatment significantly altered above-ground (shoot) biomass. High NP plots had greater above-ground biomass than control plots, but neither solo $\mathrm{N}$ nor $\mathrm{P}$ addition significantly increased above-ground biomass compared to the control. Grazing also altered above-ground biomass with greater biomass in the rabbit grazed than the fully grazed treatment (Fig. 1). Un-grazed units also had high above-ground biomass but were not significantly different from the fully grazed or rabbit grazed treatments. Total root biomass, root biomass at each depth zone $(0-15,15-30$ and $30-50 \mathrm{~cm})$ and root: shoot ratios did not differ significantly with either nutrient addition (Fig. 1a, Table 1) or grazing treatment (Fig. 1b, Table 2). A standard relationship between root biomass and root depth zone was 
observed across all treatments, with the majority of root biomass ( $75 \%$ ) in the shallowest zone $(0-15 \mathrm{~cm}), \sim 15 \%$ in the intermediate zone $(15-30 \mathrm{~cm})$ and only $\sim 10 \%$ in the deepest zone $(30-50 \mathrm{~cm})$.

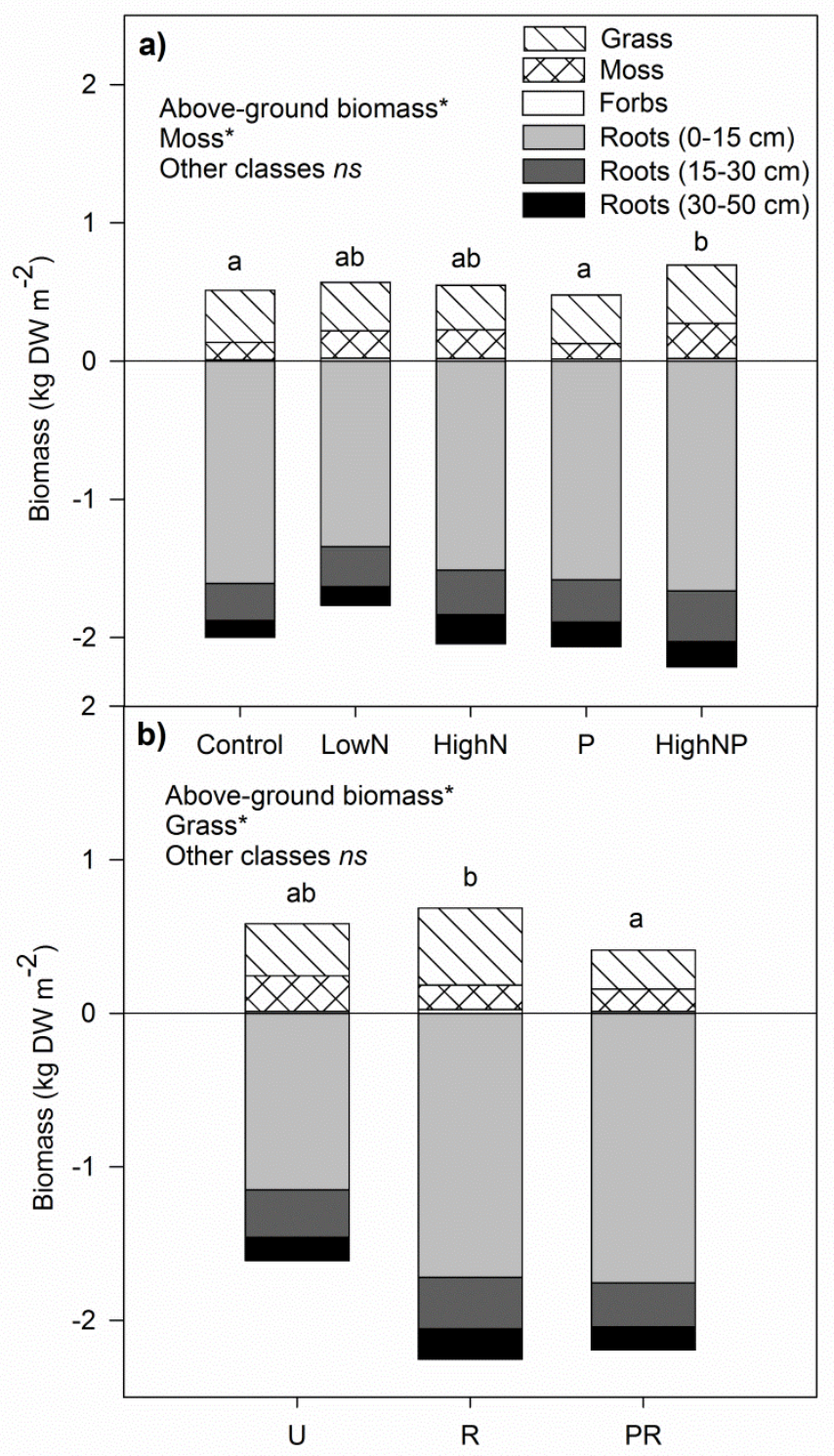

Fig. 1. Impact of nutrient addition (a) and grazing ( $b$; $U=$ un-grazed, $R=$ rabbit grazed, $P R=$ fully grazed) on above-ground (grass, moss, forbs) and below-ground root biomass. Significant differences between treatments [Ime (ANOVA); $* p<0.05$ ] indicated by different letters (Nutrient treatments: above-ground biomass and moss have same significance levels; Grazing treatments: above-ground biomass and grass have the same significance levels). Root biomass not significantly different between grazing or nutrient addition treatments. 
For broad plant functional groups, forbs accounted for $2-4 \%$ of the overall above-ground biomass, moss $25-40 \%$ and grass (+ litter) $60-70 \%$. Lichens only occurred in four quadrats so were not included in major plant functional group analysis. Nutrient addition and grazing treatments both significantly altered above-ground biomass for certain plant functional groups. Above-ground biomass was significantly greater in the High NP treatment than the control or $\mathrm{P}$ addition plots as a result of significant changes in moss biomass (Fig. 1a). Grass and forb biomass were not significantly affected by nutrient addition treatment. Above-ground biomass was significantly greater in the rabbit grazed than the fully grazed treatment as a result of the grass biomass responses (Fig. 1b).

\subsection{Soil parameters}

Soil moisture content was affected by grazing treatment with fully grazed units having higher soil moisture content than either the un-grazed or rabbit grazed treatments (Table 2). Soil temperature, $\mathrm{pH}$ and organic matter content did not differ significantly with either nutrient addition (Table 1) or grazing treatment (Table 2).

\subsection{Meso-faunal feeding activity}

Soil depth was the over-riding factor influencing leaf litter breakdown via meso-faunal feeding activity (\% per 7 days), the shallower the soil depth zone the greater the feeding rate (ANOVA: $F=111.59, p<0.001$ ). Grazing also had a significant effect (ANOVA: $F=7.86, p$ $<0.05$ ) with the fully grazed treatments showing a significantly lower meso-faunal feeding activity rate than the un-grazed and rabbit grazed treatments at most depths (Fig. 2). Neither $\mathrm{N}$ nor $\mathrm{P}$ addition had any significant effect on meso-faunal feeding activity (ANOVA: $\mathrm{F}=0.27, n s)$. 


\section{Table 1}

Soil and vegetation characteristics: nutrient addition treatment means and comparative statistics.

\begin{tabular}{lllllllll}
\hline & Control & LowN & HighN & P & HighNP & Model SE & F statistic \\
\hline Soil & & & & & & & & \\
$\quad$ Temperature $\left({ }^{\circ} \mathrm{C}\right)$ & 11.64 & 11.56 & 11.60 & 11.52 & 11.56 & $(0.050)$ & 0.150 & $n s$ \\
$\quad$ Moisture content (\%) & 20.31 & 19.14 & 24.06 & 20.63 & 22.20 & $(2.207)$ & 1.492 & $n s$ \\
$\quad$ pH & 6.13 & 6.15 & 6.11 & 6.12 & 6.02 & $(0.096)$ & 0.534 & $n s$ \\
$\quad$ Organic matter (\%) & 3.00 & 3.40 & 2.93 & 2.72 & 3.14 & $(0.432)$ & 0.688 & $n s$ \\
$\quad \begin{array}{l}\text { Vegetation } \\
\quad \text { Root: shoot ratio }\end{array}$ & 5.16 & 3.56 & 3.95 & 5.83 & 3.47 & $(0.933)$ & 2.5407 & $n s$ \\
\hline
\end{tabular}

Linear mixed effects model output

Non-significant results $n s$

\section{Table 2}

Soil and vegetation characteristics: grazing treatment means and comparative statistics.

\begin{tabular}{lllllll}
\hline & Un-grazed & Rabbit grazed & Fully grazed & Model SE & F statistic \\
\hline Soil & & & & & & \\
$\quad$ Temperature $\left({ }^{\circ} \mathrm{C}\right)$ & 11.55 & 11.55 & 11.63 & $(0.062)$ & 1.370 & $n s$ \\
$\quad$ Moisture content $(\%)$ & $17.89 a$ & $18.33 a$ & $27.59 b$ & $(1.710)$ & 20.497 & $* *$ \\
pH & 6.26 & 6.02 & 6.04 & $(0.074)$ & 6.351 & $n s$ \\
$\quad$ Organic matter $(\%)$ & 2.17 & 3.14 & 3.25 & $(0.342)$ & 1.332 & $n s$ \\
$\quad \begin{array}{l}\text { Vegetation } \\
\quad \text { Root: shoot ratio }\end{array}$ & 3.96 & 3.48 & 5.74 & $(1.675)$ & 1.013 & $n$ ns \\
\hline
\end{tabular}

Linear mixed effects model output

Significant effects indicated by $*(p<0.05), * *(p<0.01), a$ is different from $b$, non-significant results $n s$ 


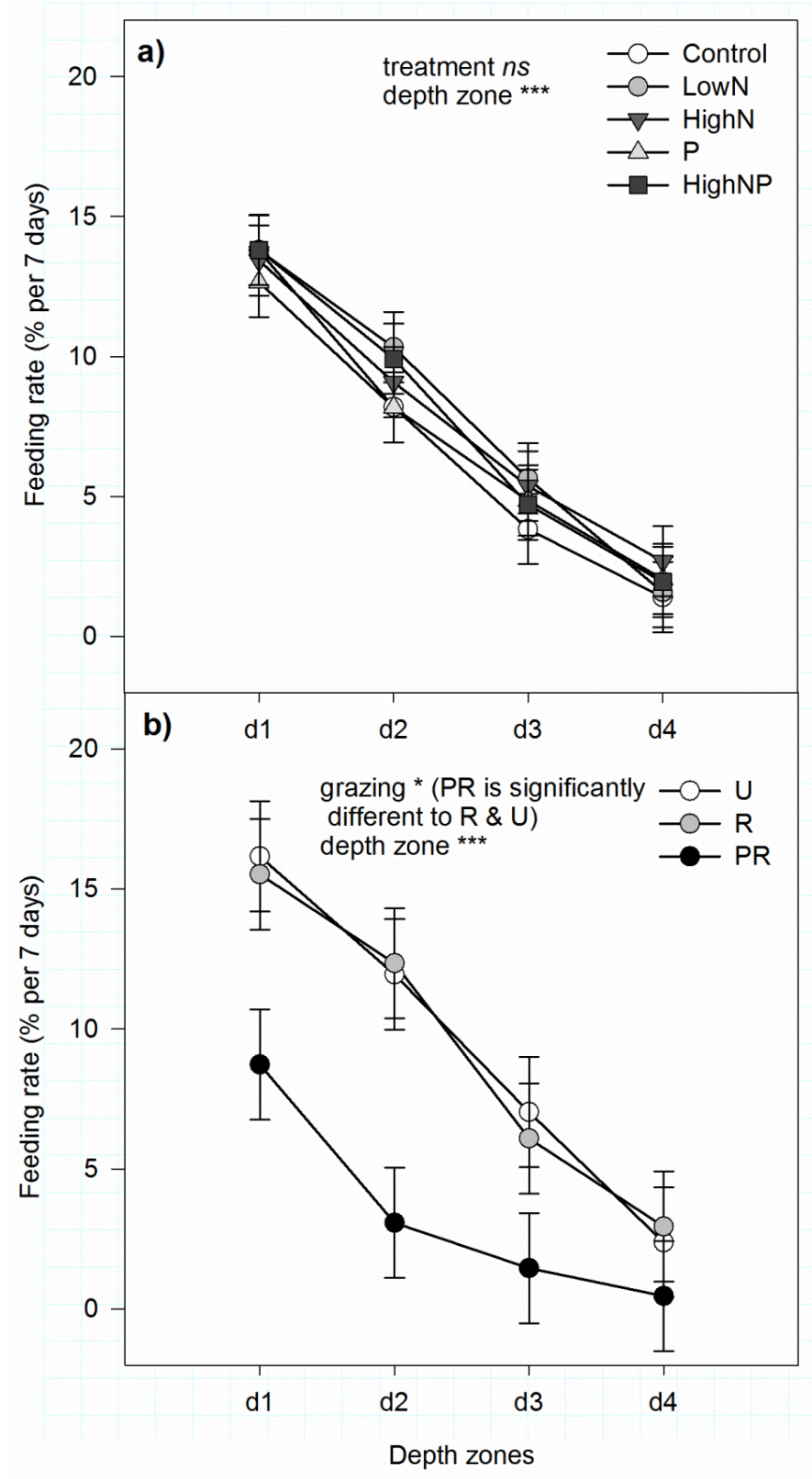

Fig. 2. Impact of nutrient addition (a), grazing ( $b ; U=$ un-grazed, $R=$ rabbit grazed, $P R=$ fully grazed) and depth zone on meso-faunal feeding activity. Significant differences [Ime (ANOVA) indicated by * $\left.\mathrm{p}<0.05,{ }^{* * *} \mathrm{p}<0.001\right]$. Error bars indicate Ime (ANOVA) model standard error.

\subsection{Nutrient cycling}

Net nitrification rate ( $\mathrm{g}^{-1}$ organic matter) appeared to be NP co-limited as it was significantly greater under the High NP treatment than either the control or the Low N treatment (Fig. 3). Grazing also had an impact with a greater net nitrification rate in the un-grazed as opposed to the rabbit or fully grazed treatments. Net ammonification rate $\left(\mathrm{g}^{-1}\right.$ organic matter) did not 
differ with either $\mathrm{N}$ or $\mathrm{P}$ nutrient addition $(\mathrm{F}=0.23, \mathrm{p}=0.92)$ or grazing $(\mathrm{F}=1.95, \mathrm{p}=0.26)$. Phosphorus mineralisation ( $\mathrm{g}^{-1}$ organic matter) also appeared to be NP co-limited as it was significantly greater under the HighNP treatment than either the control or the Low $\mathrm{N}$ treatment (Fig. 3). However, P mineralisation showed no significant difference between the grazing treatments (Fig. 4), in contrast to the response observed for net nitrification. There were no significant grazing - nutrient treatment interactions for all reported results.

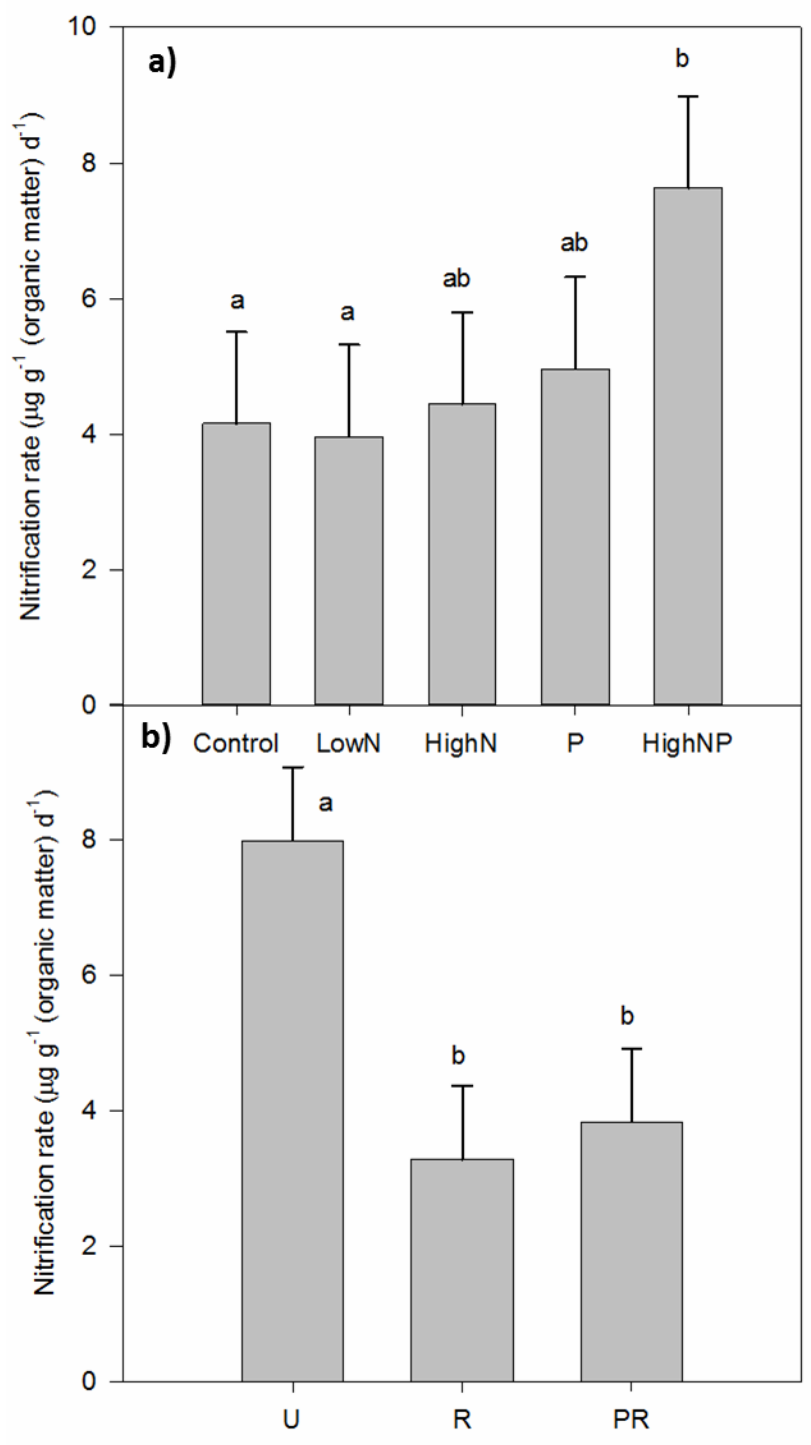

Fig. 3. Impact of nutrient addition ( $a$ ) and grazing ( $b ; U=$ un-grazed, $R=$ rabbit grazed, $P R=$ fully grazed) on soil nitrification rate. Significant differences [Ime (ANOVA); $p<0.05$ ] indicated by different letters. Error bars indicate Ime (ANOVA) model standard error. 


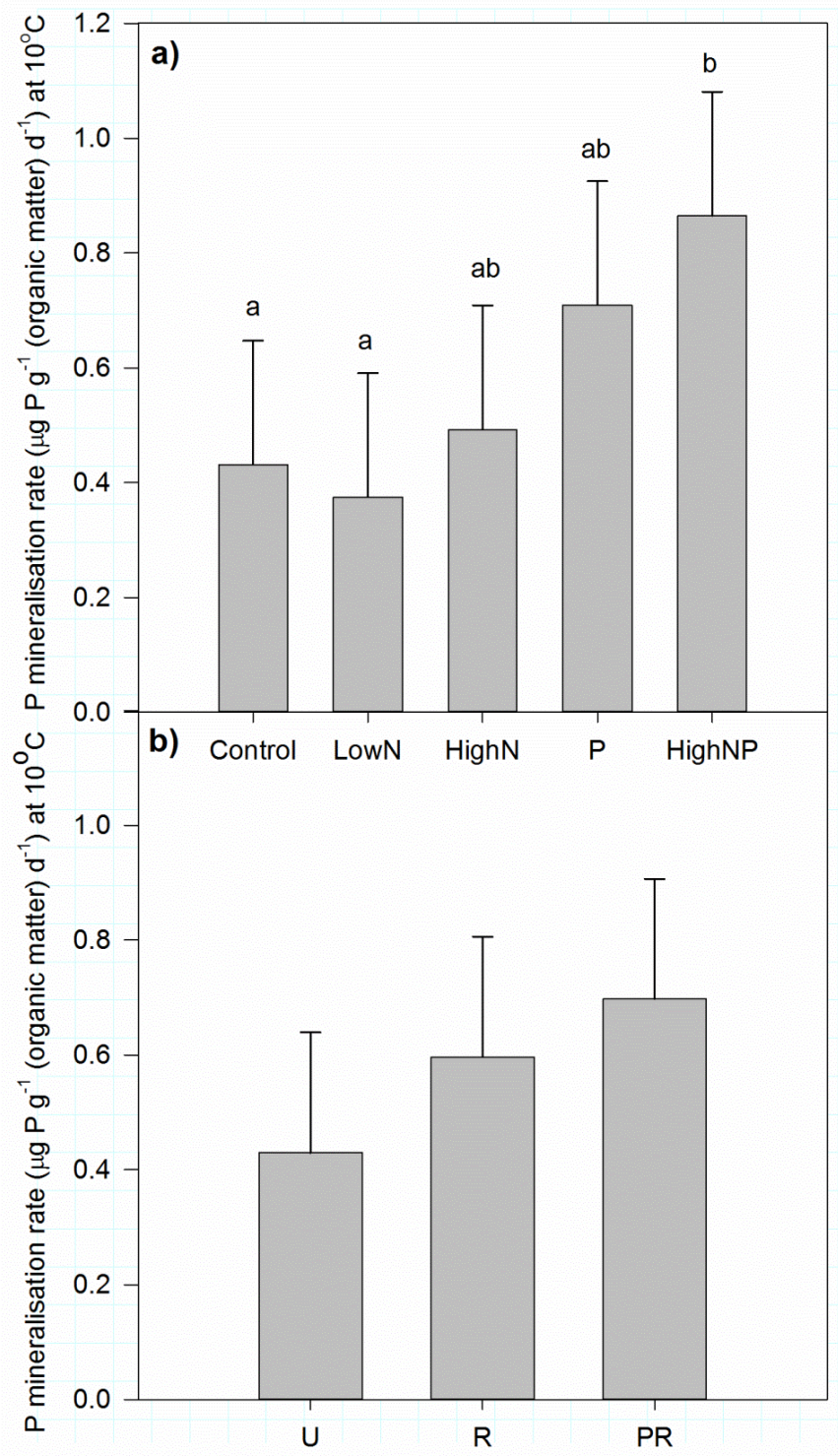

Fig. 4. Impact of nutrient addition ( $a$ ) and grazing ( $b ; U=$ un-grazed, $R=$ rabbit grazed, $P R=$ fully grazed) on soil P mineralisation rate. Significant differences [Ime (ANOVA); $p<0.05$ ] indicated by different letters. Error bars indicate Ime (ANOVA) model standard error.

\section{Discussion}

Impact of $N$ addition

The $\mathrm{N}$ addition treatments alone did not increase above-ground biomass, alter root biomass, increase meso-faunal feeding rates or alter $\mathrm{N}$ and $\mathrm{P}$ cycling. The similar lack of response in the $\mathrm{P}$ treatment, combined with significant responses observed only in the 
combined NP treatment strongly suggests this dune grassland is NP co-limited. Other low nutrient grasslands have shown a degree of NP co-limitation, with significantly greater above-ground biomass in NP treatments than in the control or with addition of $\mathrm{N}$ or $\mathrm{P}$ separately (Willems et al., 1993; Carroll et al., 2003). Across grasslands globally NP colimitation is widespread (Elser et al., 2007; Bracken et al., 2015; Fay et al., 2015). By contrast, in a Dutch study, $\mathrm{N}$ addition was reported to increase plant biomass in diverse chalk grassland, overriding any subtle P effects (Bobbink 1991), therefore not all calcareous grasslands are necessarily $\mathrm{P}$ limited. The soils at the experiment in Newborough are partly decalcified, with a $\mathrm{pH}$ around 6.1, a level at which phosphorus is not strongly bound chemically in complexes with calcium, and a similar $\mathrm{pH}$ at which sites in the Netherlands show high plant biomass (Kooijman and Besse 2002). The soils at this location are at least 140 years old (Jones et al. 2008) and many decades of grazing may have depleted soil P levels, leading to a situation where the site is NP co-limited.

Whilst not significant, both the low and the high $\mathrm{N}$ treatments increased moss biomass by around $60 \%$ relative to the control, highly consistent with the findings of Plassmann et al. (2009). They discovered, using the same experimental units, that after only two years of treatment addition, there were significant increases in the $\mathrm{N}$ pool in bryophyte biomass in the low and the high $\mathrm{N}$ treatments due to both an increase in biomass and an increase in tissue $\mathrm{N}$. This reveals consistency in the ecosystem response over short to longer timescales, and suggests that much of the additional $\mathrm{N}$ being deposited on sand dune grasslands is being stored in the plant or soil system, primarily in mosses but also in rhizomes of the sand sedge Carex arenaria (Jones et al. 2010). In this way, bryophytes can play a role in mediating access to nutrients by higher plants (Bracken et al., 2015). While many bryophytes are highly sensitive to $\mathrm{N}$, the increase in bryophyte biomass here is not surprising as responses are species-specific (Armitage et al., 2012). However, experiments applying much higher loadings of $\mathrm{N}$ in calcareous grasslands, low nutrient fens and ombrotrophic bogs have shown a decline in moss cover and an increase in vascular plants, particularly graminoid cover (Carroll et al. 2003; Cusell et al., 2014; Wu and Blodau, 2015).

Nutrient cycling is important in low-nutrient calcareous grasslands as it determines plant available $\mathrm{N}$ and $\mathrm{P}$, both of which are limiting factors for plant primary productivity (Bardgett 
et al., 2011). Plants and microbes often compete for key nutrients in nutrient poor systems, however microbes can also facilitate plant nutrient uptake by boosting $\mathrm{N}$ and $\mathrm{P}$ mineralisation in the rhizosphere (Marschner et al., 2011; Dijkstra et al., 2015). The NP colimitation effect on nutrient cycling reported here has not been widely reported elsewhere. In other studies, both short and long term $\mathrm{N}$ additions in other studies increased net $\mathrm{N}$ mineralization, nitrification rates and leaching of nitrate in both improved and calcareous grasslands (Wedin and Tilman, 1996; Ledgard et al., 1998; Unkovich et al., 1998). However, these experimental studies all added $\mathrm{N}$ at rates of $50-300 \mathrm{~kg} \mathrm{~N} \mathrm{ha}^{-1}$ year $^{-1}$, considerably overshooting our more realistic levels of $7.5-15 \mathrm{~kg} \mathrm{~N}^{-1}$ year $^{-1}$, which much more accurately reflect the situation of long-term increased deposition from atmospheric nitrogen which affect a considerable proportion of semi-natural habitats in Europe and indeed globally (Phoenix et al. 2006). Other experiments may not have shown NP colimitation due to previous application of $\mathrm{P}$ (as farmyard manure or fertiliser) in improved grasslands. Despite greater plant biomass in the high NP treatment, there was no trophic cascade, i.e., no impacts on meso-faunal feeding rates, and meso-faunal feeding rates in turn did not appear to alter rates of nutrient cycling.

\section{Grazing management}

Not surprisingly, grazing by ponies, cattle and rabbits reduced the above-ground biomass. However, the high biomass in the rabbit only treatments requires further explanation. As a result of the decline in rabbit population prior to the measurements in this study, the rabbit grazed units combined elements of both un-grazed and grazed systems. Characteristics of un-grazed grassland included: a tall above-ground canopy (due to grass re-growth following rabbit decline), low soil moisture content and high meso-faunal feeding rates indicative of aerobic un-compacted soil conditions. However, residual characteristics of (rabbit) grazing on some ecological processes remained, such as root growth and nutrient cycling effects. Removal of grazing had no effect on forb biomass, this is surprising as removal of large grazing herbivores tends to lead to a decrease in the abundance of flowering plants and a corresponding increase in grass cover (Pykälä, 2003; Plassmann et al. 2010; Ford et al., 2012a). 
It is often suggested that more intensively grazed land is characterised by faster bacterial nutrient cycling and un-grazed grassland will have slower fungal cycling (McNaughton et al., 1997; Bardgett et al., 1998). However, in this study net nitrification rate was greatest in the un-grazed grassland, supporting an opposing view that grazing by large herbivores can decrease nutrient cycling (van Wijnen et al., 1997; Bakker, 2003; Ford et al., 2013). This may be because cattle distribute $\mathrm{N}$ unevenly via their faeces and urine, with pulses of nutrients being patchy in both space and time, whereas smaller mammals such as voles, present within un-grazed units, return nutrients to the soil more uniformly (Rotz et al., 2005). In this study, grazing appeared to result in a de-coupling between $\mathrm{N}$ and $\mathrm{P}$ cycling. The reasons for this are unclear, but may help shed some light on mechanisms controlling litter phosphatase activity. Further work would be required to unpick the mechanisms behind this effect, and its implications.

\section{Implications for management}

The $\mathrm{N}$ treatments added to the background deposition take the total $\mathrm{N}$ loads to 18.5 and 26 $\mathrm{kg} \mathrm{N} \mathrm{ha-1} \mathrm{yr}^{-1}$, well above the maximum of the critical load range for this habitat of $8-15 \mathrm{~kg}$ $\mathrm{N} \mathrm{ha}{ }^{-1} \mathrm{yr}^{-1}$ (Bobbink and Hettelingh 2013). Although no impact is yet apparent on plant biomass or nutrient availability compared with the control, the quantity of moss biomass suggests that $\mathrm{N}$ may be stored in the plant or soil system, as in Bracken et al. (2015), with potential unknown consequences in the future. Estimates of additional $\mathrm{N}$ deposition at this site from a nearby intensive poultry unit show that increases in $\mathrm{N}$ deposition are likely to augment soil $\mathrm{N}$ and soil $\mathrm{C}$ pools over time (Jones et al. 2013). It should also be borne in mind that since the background deposition is near the mid-point of the critical load range for fixed dune grasslands there may already be impacts including reduced species richness and a shift towards $\mathrm{N}$ tolerant species. For example, data in Field et al. (2014) show that even a relatively small increase in $\mathrm{N}$ deposition from 8 to $11 \mathrm{~kg} \mathrm{~N}$ (within the critical load range) may result in a loss of species richness in dune grasslands. This has implications for conservation management in high $\mathrm{N}$ deposition areas where sites may already have experienced $\mathrm{N}$ impacts at the time of designation, but do not show obvious damage due to $\mathrm{N}$ since designation. Furthermore, if sites are NP co-limited, the continued accumulation of $\mathrm{N}$ may result in hidden impacts which will only become apparent in the future. There is also 
evidence that $\mathrm{P}$ limitation may not fully protect habitats in the long-term from $\mathrm{N}$-deposition impacts mediated by plant competition. Studies across a range of ecosystems show that increasing $\mathrm{N}$ availability can enhance $\mathrm{P}$ cycling rates, by allocating excess $\mathrm{N}$ to phosphatase enzymes, thereby delaying the onset of $\mathrm{P}$ limitation and offering a pathway by which plants and ecosystems can adjust to changes in $\mathrm{N}$ and $\mathrm{P}$ supplies (Rowe et al., 2007; Marklein and Houlton, 2012).

\section{Acknowledgements}

This work was co-funded by the UK Department for Environment Food and Rural Affairs (DEFRA) and the Natural Environment Research Council (NERC).

\section{References}

Armitage, H.F., Britton, A.J., van der Wal, R., Pearce, I.S.K., Thompson, D.B.A., Woodin, S.J., 2012. Nitrogen deposition enhances moss growth, but leads to an overall decline in habitat condition of mountain moss-sedge heath. Global Change Biology 18, 290-300.

Bakker, E.S., 2003. Herbivores as mediators of their environment: the impact of large and small species on vegetation dynamics. PhD-thesis Wageningen University, Wageningen, The Netherlands. ISBN 90-5808-878-2, pp. 184.

Bardgett, R.D., Leemans, D.K., 1995. The short-term effects of cessation of fertiliser applications, liming, and grazing on microbial biomass and activity in a reseeded upland grassland soil. Biology and Fertility of Soils 19, 148-154.

Bardgett, R.D., Wardle, D.A., Yeates, G.W., 1998. Linking above-ground and below-ground interactions: how plant responses to foliar herbivory influence soil organisms. Soil Biology and Biochemistry 30, 1867-1878.

Bardgett, R.D., Campbell, C.D., Emmett, B.A., Jenkins, A., Whitmore, A.P., 2011. Chapter 13: Supporting services. In: The UK National Ecosystem Assessment Technical Report, UK National Ecosystem Assessment, UNEP-WCMC, Cambridge, UK. 
Bobbink, 1991. Effects of nutrient enrichment in Dutch chalk grassland. Journal of Applied Ecology 28, 28-41.

Bobbink, R., Hicks, K., Galloway, J., Spranger, T., Alkemade, R., Ashmore, M., Bustamante, M., Cinderby, S., Davidson, E., Dentener, F., Emmett, B., Erisman, J.W., Fenn, M., Gilliam, F., Nordin, A., Pardo, L. De Vries, W., 2010. Global assessment of nitrogen deposition effects on terrestrial plant diversity: a synthesis. Ecological Applications 20, 30-59.

Bobbink, R., Hettelingh, J.P. 2011. Review and revision of empirical critical loads and doseresponse relationships: Proceedings of an expert workshop, Noordwijkerhout, 23-25 June 2010. Coordination Centre for Effects, RIVM, NL.

Bobbink, R., Willems, J.H., 1987. Increasing dominance of Brachypodium pinnatum (L.) Beauv. In chalk grasslands: a threat to a species-rich ecosystem. Biological Conservation 40, 301-314.

Bracken, M.E.S., Hillebrand, H., Borer, E.T., Seabloom, E.W., Cebrian, J., Cleland, E.E., Elser, J.J., Gruner, D.S., Harpole, W.S., Ngai, J.T., Smith, J.E., 2015. Signatures of nutrient limitation and co-limitation: responses of autotroph internal nutrient concentrations to nitrogen and phosphorus additions. Oikos 124, 113-121.

Carroll, J.A., Caporn, S.J.M., Johnson, D., Morecroft, M.D., Lee, J.A., 2003. The interactions between plant growth, vegetation structure and soil processes in semi-natural acidic and calcareous grasslands receiving long-term inputs of simulated pollutant nitrogen deposition. Environmental pollution 121, 363-376.

Cussel, C., Kooijman, A., Lamers, L.P.M., 2014. Nitrogen or phosphorus limitation in rich fens? - Edaphic differences explain contrasting results in vegetation development after fertilization. Plant Soil 384, 153-168.

Dijkstra, F.A., Hu, M., Johansen, M.P., Harrison, J.J., Keitel, C., 2015. Plant and microbial uptake of nitrogen and phosphorus affected by drought using ${ }^{15} \mathrm{~N}$ and ${ }^{32} \mathrm{P}$ tracers. Soil Biology and Biochemistry 82, 135-142.

Elser, J.J., Bracken, M.E.S., Cleland, E.E., Gruner, D.S., Stanley, Harpole, W.S., Hillebrand, H., Ngai, J.T., Seabloom, E.W., Shurin, J.B., Smith, J.E., 2007. Global analysis of nitrogen and 
phosphorus limitation of primary producers in freshwater, marine and terrestrial ecosystems. Ecology Letters 10, 1135-1142.

Fay, P.A., Prober, S.M., Yang, L.H., 2015. Grassland productivity limited by multiple nutrients. Nature Plants, doi:10.1038/nplants.2015.80

Ford, H., Garbutt, A., Jones, D.L., Jones, L., 2012a. Impacts of grazing abandonment on ecosystem service provision: Coastal grassland as a model system. Agriculture, Ecosystems and Environment 162, 108-115.

Ford, H., Garbutt, A., Jones, L., Jones, D.L., 2012b. Methane, carbon dioxide and nitrous oxide fluxes from a temperate salt marsh: Grazing management does not alter Global Warming Potential. Estuarine, Coastal and Shelf Science 113, 182-191.

Ford, H., Rousk, J., Garbutt, A., Jones, L., Jones, D.L., 2013 Grazing effects on microbial community composition, growth and nutrient cycling in salt marsh and sand dune grasslands. Biology and Fertility of Soils 49, 89-98.

Field C., Dise N., Payne, R., Britton, A., Emmett, B., Helliwell R., Hughes S., Jones L., Leake J., Leith I., Phoenix G., Power S., Sheppard L., Southon G., Stevens C., Caporn S.J.M., (2014). Nitrogen drives plant community change across semi-natural habitats. Ecosystems 17, 864877.

Galloway, J.N., Dentener, F.J., Capone, D.G., Boyer, E.W., Howarth, R.W., Seitzinger, S.P., Asner, G.P., Cleveland, C.C., Green, P.A., Holland, E.A., Karl, D.M., Michaels, A.F., Porter, J.H., Townsend, A.R., Vörösmarty, C.J., 2004. Nitrogen cycles: past, present, and future. Biogeochemistry 70, 153.226.

Gong, S., Guo, R., Zhang, T., Guo, J., 2015. Warming and nitrogen addition increase litter decomposition in a temperate meadow ecosystem. PLoS ONE 10, e0116013, doi:10.1371/journal.pone.0116013.

Jeffrey, D.W., Pigott, C.D., 1973. The response of grasslands on sugar-limestone in Teesdale to application of phosphorus and nitrogen. Journal of Ecology 61, 85-92. 
Jones L., Nizam M.S., Reynolds B., Bareham S., Oxley E.R.B., 2013. Upwind impacts of ammonia from an intensive poultry unit. Environmental Pollution 180, 221-228.

Jones, L., Provins, A., Harper-Simmonds, L., Holland, M., Mills, G., Hayes, F., Emmett, B.A., Hall, J., Sheppard, L.J., Smith, R., Sutton, M., Hicks, K., Ashmore, M., Haines-Young, R. 2014. A review and application of the evidence for nitrogen impacts on ecosystem services. Ecosystem Services 7, 76-88.

Jones, M. L. M., Hodges, G., Mills, G., 2010. Nitrogen mediates some ozone effects but exacerbates others in a rhizomatous sedge. Environmental Pollution 158, 559-565.

Jones, M.L.M., Sowerby, A., Williams, D.L., Jones, R.E., 2008. Factors controlling soil development in sand dunes: evidence from a coastal dune soil chronosequence. Plant and Soil 307, 219-234.

Kooijman, A.M., Besse, M., 2002. The higher availability of $\mathrm{N}$ and $\mathrm{P}$ in lime-poor than in limerich coastal dunes in the Netherlands. Journal of Ecology 90, 394-403.

Ledgard, S.F., Jarvis, S.C., Hatch, D.J., 1998. Short-term nitrogen fluxes in grassland soils under different long-term nitrogen management regimes. Soil Biology and Biochemistry 30, $1233-1241$.

Maddock, A. 2008. UK Biodiversity Action Plan Priority Habitat Descriptions, Coastal Sand Dunes, JNCC report, UK.

Marklein, A.R., Houlton, B.Z., 2012. Nitrogen inputs accelerate phosphorus cycling rates across a wide variety of terrestrial ecosystems. New Phytologist 193, 696-704.

Marschner, P., Crowley, D., Rengel, Z., 2011. Rhizosphere interactions between microorganisms and plants govern iron and phosphorus acquisition along the root axis model and research methods. Soil Biology and Biochemistry 43, 883-894.

McNaughton, S.J., Banyikwa, F.F., McNaughton, M.M., 1997. Promotion of the cycling of diet-enhancing nutrients by African grazers. Science 278, 1798-1800.

Millett, J., Edmondson, S., 2013. The impact of 36 years of grazing management on vegetation dynamics in dune slacks. Journal of Applied Ecology 50, 1367-1376. 
Morecroft, M.D., Sellers, E.K., Lee, J.A., 1994. An experimental investigation into the effects of atmospheric nitrogen deposition on two semi-natural grasslands. Journal of Ecology 82, 475-483.

Olsen, S.R., Cole, C.V., Watanbe, F.S., Dean, L.A., 1954. Estimation of available phosphorus in soils by extraction with sodium bicarbonate. Circular 939, United States Department of Agriculture Washington DC.

Phoenix, G.K. et al., 2006. Atmospheric nitrogen deposition in world biodiversity hotspots: the need for a greater global perspective in assessing $\mathrm{N}$ deposition impacts. Global Change Biology 12, 470-476.

Phoenix, G.K. et al., 2012. Impacts of atmospheric nitrogen deposition: responses of multiple plant and soil parameters across contrasting ecosystems in long-term field experiments. Global Change Biology 18, 1197-1215.

Plassmann, K., Jones, M.L.M., Edwards-Jones, G., 2010. Effects of long-term grazing management on sand dune vegetation of high conservation interest. Applied Vegetation Science 13, 100-112.

Plassmann, K., Edwards-Jones, G., Jones, M.L.M., 2009. The effects of low levels of nitrogen deposition and grazing on dune grassland. Science of the Total Environment 407, 13911404.

Pykälä, J. (2003) Effects of restoration with cattle grazing on plant species composition and richness of semi-natural grasslands. Biodiversity and Conservation 12, 2211-2226.

R Development Core Team. 2014. R: A Language and Environment for Statistical Computing. R Foundation for Statistical Computing, Vienna, Austria, http://www.r-project.org.

Robertson, G.P., Coleman, D.C., Bledsoe, C.S., Sollins, P.H., 1999. Standard soil methods for long-term ecological research, Oxford University Press.

Rodwell, J.S., 2000. British Plant Communities, Volume 5. Maritime communities and vegetation of open habitats. Cambridge University Press, UK. 
RoTAP. 2012. Review of transboundary air pollution: acidification, eutrophication, ground level ozone and heavy metals in the UK. Contract Report to the Department for Environment, Food and Rural Affairs. Centre for Ecology \& Hydrology.

Rotz, C.A., Taube, F., Russelle, M.P., Oenema, J., Sanderson, M.A., Wachendorf, M., 2005. Whole-farm perspectives of nutrient flows in grassland agriculture. Crop Science 45, 21392159.

Rowe, E.C., Smart, S.M., Kennedy, V.H., Emmett, B.A., Evans, C.D., 2007. Nitrogen deposition increases the acquisition of phosphorus and potassium by heather Calluna vulgaris. Environmental Pollution 155, 201-207.

Stevens, C., Dupre, C., Dorland, E., Gaudnik, C., Gowing, D.J.G., Diekmann, M., Alard, D., Bobbink, R., Corcket, E., Mountford, J., Vandvik, V., Aarrestad, P., Muller, S., Dise, N.B. 2011. Grassland species composition and biogeochemistry in 153 sites along environmental gradients in Europe. Ecology 92, 7, p. 1544.

Ten Harkel, M.J., van der Meulen, F., 1996. Impact of grazing and atmospheric nitrogen deposition on the vegetation of dry coastal dune grasslands. Journal of Vegetation Science $6,445-452$.

Unkovich, M., Jamieson, N., Monaghan, R., Barraclough, D., 1998. Nitrogen mineralisation and plant nitrogen acquisition in a nitrogen-limited calcareous grassland. Environmental and Experimental Botany 40, 209-219.

van den Berg, L.J.L., Tomassen, H.B.M., Roelofs, J.G.M., Bobbink, R., 2005. Effects of nitrogen enrichment on coastal dune grassland: A mesocosm study. Environmental Pollution $138,77-85$.

van Dijk, H.W.J. 1992. Grazing domestic livestock in Dutch coastal dunes: Experiments, experiences and perspectives. In: Carter, R.W.G., Curtis, T.G.F. \& Sheehy-Skeffington, M.J. (eds.) Coastal Dunes, pp. 235- 250. Balkema, Rotterdam.

van Wijnen, N.J., Wal, R., Bakker, J.P., 1997. The impact of herbivores on nitrogen mineralization rate: consequences for salt-marsh succession. Oecologia 118, 225-231. 
Vitousek, P.M., Porder, S., Houlton, B.Z., Chadwick, O.A., 2010. Terrestrial phosphorus limitation: mechanisms, implication, and nitrogen-phosphorus interactions. Ecological Applications 20, 5-15.

Wedin, D.A., Tilman, D., 1996. Influence of nitrogen loading and species composition on the carbon balance of grasslands. Science 274, 1720-1723.

Willems, J.H., Peet, R.K., Bik, L., 1993. Changes in chalk-grassland structure and species richness resulting from selective nutrient additions. Journal of Vegetation Science 4, 203212.

Wu, Y., Blodau, C., 2015. Vegetation composition in bogs is sensitive to both load and concentration of deposited nitrogen: a modelling analysis. Ecosystems 18, 171-185. 